\title{
FEATURES OF SPECIFIC IMMUNITY FORMATION IN CATTLE AFTER VACGINATION AGAINST ANIMALS ANTHRAX WITH VACCINE OF UA-07 "ANTRAVAK" STRAIN
}

\section{O. RUBLENKO, PhD in Veterinary \\ BilaTserkva National Agrarian University}

V. G. SKRYPNYK, SCD in Veterinary

The State Scientific Research Institute of Laboratory Diagnostic and Veterinary Sanitary Expertise

The results of comparison of titers of antibodies anthrax in the serum of cattle immunized with a vaccine against anthrax strain of animals from Bacillus anthracis UA-07 "Antravak" are presented in the paper. The vaccine causes a stimulating effects in animals of all experimental groups, especially in the third, where the anthrax titers of antibodies were the highest. The lowest indicators of antibodies were found in the first group of animals. Indicators of the third group experimental animals blood serum $(\operatorname{Lim} 1: 40-1: 160)$ were significantly higher by $0,55 \lg 2(\operatorname{Lim} 1: 80-1: 160)$ from the indicators in the first experimental group. The obtained results suggest the expediency of application of the animals anthrax vaccine of UA-07 Bacillus anthracis "Antravak" strain for cattle immunization.

Introduction. Anthrax is a zoonotic disease, which has keeps being registered in different areas of the world which signifies the constant threat of the disease emergence and spread.

One of the current ways of increasing efficiency of anthrax vaccines is applying advanced technologies, protein engineering[1].However, among its disadvantages is that fact the anthrax antigen is easily destroyed by enzymes proteases [2] Therefore, modern veterinary science faces urgent problems of developing effective preventive measures in animals against anthrax.

ON-time vaccination with full coverage of all livestock, animal revaccination of all kinds,strict control over the gravesites remnants of corpses after burning, observance and enforcement of operating instructions during improving actions in disadvantaged locations makes the basis for anthrax prevention [3-4].

G. L .Skadovsky received the primary material in the laboratory of his own manor located in our country and later on professor L. S. Tsenkovskyy from the Kharkiv University produced the first vaccine for the vaccination from it. Thus, the first vaccinations were carried out by the local doctor of veterinary medicine P. V. Voznesensky (1333 sheep owned by Skadovsky G. L. were vaccinated). Having examined the immune system of 30 vaccinated and 10 unvaccinated sheep there was recorded:«On the basis of foregoing, the Commission made completely sure, that the vaccine prepared by Professor Tsenkovsky, protect sheep 
against infecting with natural contagion of anthrax».The Decree of the Ministry of Internal Affairs committee`s meeting allowed the vaccination against anthrax in Kherson, Kharkiv and Ekaterinoslav provinces and there was developed the draft of «Rules on production of sheep anthrax vaccines» [5].

Since then and during Ukraine independence there has been developed a number of vaccines against anthrax in animals, but only two preparations are industrially manufactured for anthrax prevention: "The live vaccine against anthrax in animals from K-79Z strain», «The live spore vaccine against anthrax in animals from the "SB" strain (dry, liquid, preserved [6]. The vaccine is considered effective, when after its introduction develops the long protection against the given pathogen. Vaccines are considered to be efficient if they meet the requirements on quality control methods against anthrax spore vaccine [7-9], i.e. immunogenicity (to stimulate a sufficient protective response), safety (incidence of adverse reactions) and epidemiological efficacy (disease decrease among the vaccinated animals) [10-11].

Thus, despite developing a large number of vaccines against animals anthrax, there is still a significant problem of obtaining the optimum vaccine, that would meet the requirements of scientists and stop the disease outbreaks [12]. A large number of permanently disadvantaged areas in our country makes a potential threat of epizootic and epidemiological complications [13-14].

Therefore, understanding the necessity of farm animals efficient vaccination, with taking into consideration the historical aspects and requirements of some current Ukrainian legislation will result in minimal losses of animals and costs.

The purpose and objectives of the study is to determine the duration of immunity in cattle after immunization with vaccine against animals anthrax of UA-07 "Antravak" strain.

Materials and methods. The study was performed on cattle at Kherson State institution biological factory, at the State Scientific Control Institute of Microorganisms Biotechnology and Strains (SSCIMBS), and at the Department of Microbiology and Virology of Bila Tserkva National Agrarian University (BNAU).

Animal vaccine against anthrax UA-07 Bacillus anthracis "Antravak" strain was produced by Kherson State institution biological factory.

The research the animals were selected and divided into groups by age: 3-6 months old (group 1), 6-12 months old (2nd group) and adults (over 12 months old) animals (3rd group). The animals were vaccinated subcutaneously with the doses recommended for vaccination of 3 to 6 months aged animals - $0,3 \mathrm{sm}^{3}$; over 6 months aged $0,5 \mathrm{sm}^{3}$. Animals of the control groups were injected subcutaneously instead of animal anthrax vaccine of UA-07 Bacillus anthracis "Antravak" strain with sterile saline in a volume corresponding to vaccine doses.

The cattle was injected in the middle third portion of the neck with a syringe according to aseptic requirements. The animals were had been examined for 12 months afterwards for 10 days after vaccination daily. The animal's body temperature was controlled and condition of the animal after vaccination was within the physiological norm.

Serum antibody titers were determined by the RHA method (using «Diagnosticum erythrocyte antigen anthrax dry», (Kazakh Scientific Center for Quarantine and Zoonotic Diseases named after M. Aykimbaev, Kazakhstan),according to the instructions), before vaccination and 21 days, 3, 6 and 12 months after animals vaccination with anthrax vaccine of UA-07 Bacillus anthracis"Antravak" strain. The serological tests evaluation was performed by Lyarski`s method (1980) [15].

Results and discussion. The research results are presented in Figure 1. The figure analysis shows that serum anthrax antibodies were found the remains in the range of 1:10 to 1:40 prior to cattle vaccination against anthrax 
with UA-07 Bacillus anthracis "Antravak" strain.In the first group cattle (Fig. 1) antibody titers were $1: 10$, in the second $-1: 10-1: 20$, in the third $-1: 20$. It should be noted, that the first group of control animals titer indicators were $1: 10(G=10,0)$, in the second $1: 10-1: 20$ $(\mathrm{G}=16,82)$, in the third $1: 20(\mathrm{G}=20,0)$.

A significant increase $(\mathrm{p}<0.001)$ in average of geometric parameters $(\mathrm{G})$ titers and concentration of antibody titers was revealed in the serum of all animal research groups 21 days later: in the first experimental group $\log _{2}$ increased from 3,32 to $8,32 \pm 0,22(\operatorname{Lim} 1: 160-$ $1: 640)$, in the second - from 4,32 to $8,45 \pm 0,12$ (Lim 1:320 - 1:640), and in the third - from 4,32 to $8,59 \pm 0,14(\operatorname{Lim} 1: 320-1: 640)$. There was noted the decrease in titers to $\lg _{2} 1,66 \pm 0,95$ In the blood serum in the third control animal group, but in the first and second groups the titers were not found. The indicators in the third animal group were significantly higher than those in the first and second groups.

The titers tend to decrease 3 months after vaccination in the first experimental group animals serum by $0,14 \lg _{2}$, by 0.13 - in the other (Fig. 2) and by $0.09 \log _{2}$ in the third group of animals as compared with those obtained after 21 days of the immuni- zation, but all indicators were significantly higher $(p<0.001)$ compared with those obtained before the animal vaccination.

In the control group animal serum the antibody titers were missing and subsequently were not detected. Indicators in the third group of animals were significantly higher than those in the first and second groups.

According to the study, 6 months after vaccination antibody titers decreased in all experimental groups animals.Antibody titers of the first group ranged 1:160-1:320 $(\mathrm{G}=$ $215,34)$ in animal serum which was significantly higher from indicators before the vaccination, but were not significantly lower (by $0,43 \lg _{2}$ ) of the indicators, obtained after 3 months after vaccination.Indicators of the second experimental group animals significantly $(\mathrm{p}<0.05)$ decreased by $0,5 \lg _{2}$ as compared to the previous data, but also remained significantly $(\mathrm{p}<0.001)$ higher as compared with indicators, obtained before the animals vaccination. The indicators of antibody titers in the third experimental group animals ranged 1:160-1:320 $(\mathrm{G}=109,63)$. They were significantly $(\mathrm{p}<0.05)$ lower than the previous data at $0,37 \lg 2$, but remained significantly higher as compared with the original data $(\mathrm{p}$

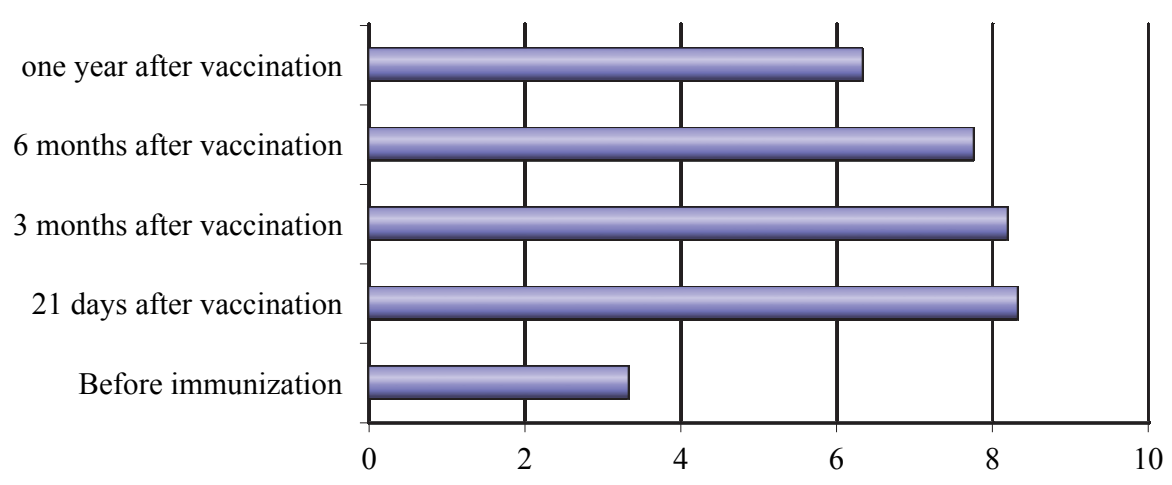

$\square$ Indicators of titers anthrax antibodies in the serum of cattle

Fig. 1. Dynamics of average geometrical indicators antibody titers in serum in first group animals, vaccinated with anthrax UA-07 Bacillus anthracis "Antravak" strain 


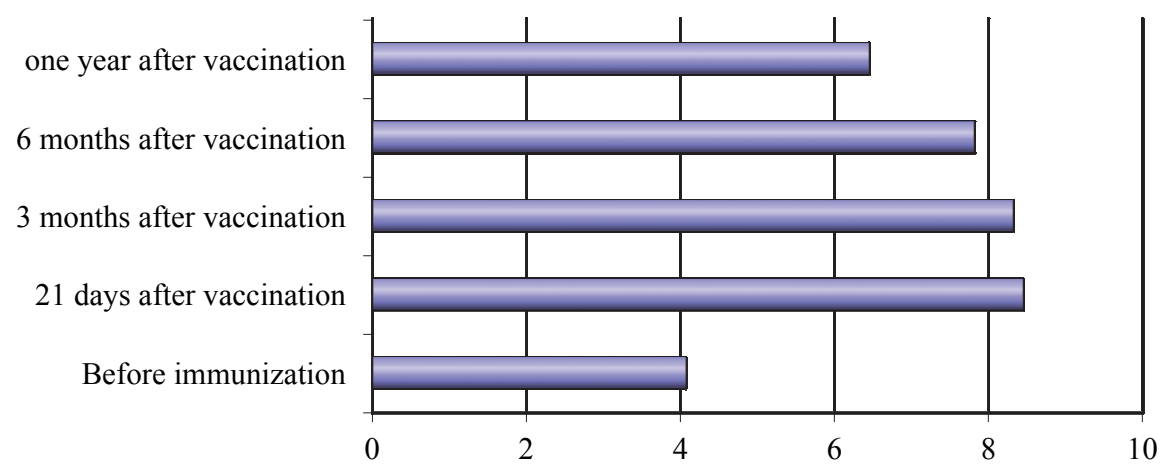

$\square$ Indicators of titers anthrax antibodies in the serum of cattle

Fig. 2. Dynamics of average geometrical indicators antibody titers in serum in the second group animals, vaccinated against anthrax UA-07 Bacillus anthracis "Antravak" strain.

$<0.001)$. Indicators of the third group animals were significantly higher than those in the first and the second groups.Later on, a year after vaccination, the anthrax antibody titers of animals in the research groups kept declining: in the first group - to 6,32 $\pm 0,22 \lg _{2}$ ( $\mathrm{Lim}$ $1: 40-1: 80)$, in the second - to $6,45 \pm 012 \lg _{2}$ (Lim 1:320 - 1:640), in the third (Fig. 3) - to $6,77 \pm 0,16 \lg _{2}(\operatorname{Lim} 1: 80-1: 160)$.

It should be noted that the indicators of blood serum of the third experimental group animals (Lim 1:40 - 1:160) were significantly higher by $0,55 \lg _{2}(\operatorname{Lim} 1: 80-1: 160)$ from those in the first experimental group.
Comparison of anthrax antibodies level in the serum of the cattle immunized with a vaccine against anthrax of UA-07 Bacillus anthracis "Antravak" strain indicates that the vaccine caused significantly higher formation of antibodies in the third group animals.

\section{Conclusions}

The research has found that the vaccine against anthrax of UA-07 Bacillus anthracis "Antravak" strain resulted in synthesis of anthrax antibodies in the cattle serum, especially in the third group. The indicators of antibodies in the first, the youngest, group were the lowest.Thus, the research

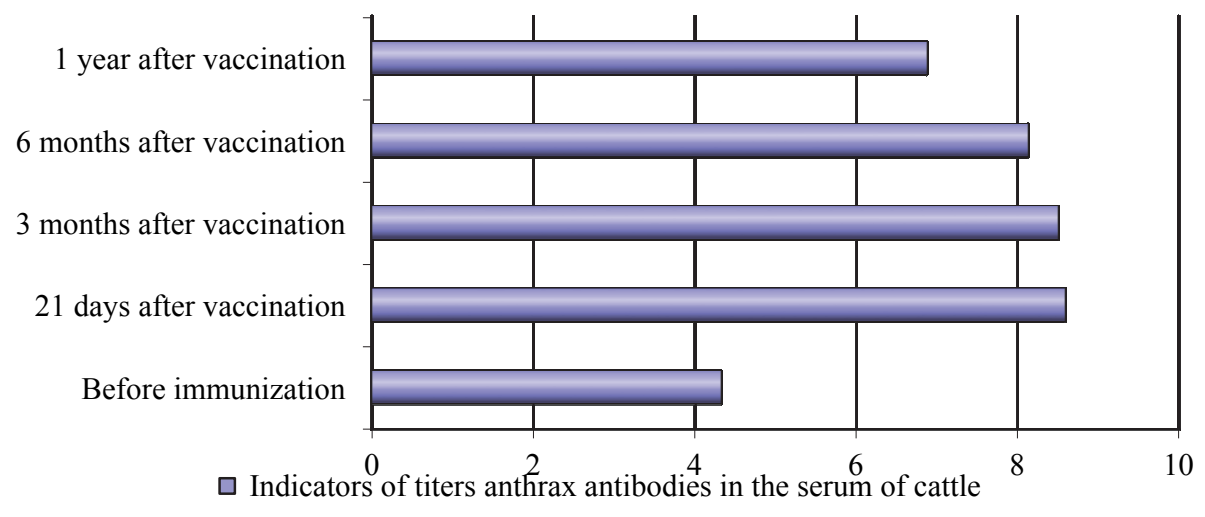

Fig. 3. Dynamics of average geometrical indicators of antibody titers in serum in the third group animals, vaccinated against anthrax with UA-07 Bacillus anthracis "Antravak" strain. 
results suggest the expediency of the vaccine application against anthrax of UA-07 Bacillus anthracis "Antravak" strain for cattle immunization.
Prospect for further research is to study the duration of immunity in other animal classes owing to vaccination of animals against anthrax of UA-07 Bacillus anthracis "Antravak" strain.

\section{References}

1. Barkova, I. A., Barkov, A. M., Alekseev, V. V., Lipnickij A. V. (2010). Species-specific whey against antigens of surface structures of Bacillus anthracis strains. Clinical Laboratory Services, 11, 51-54.

2. Piemov, E. V. (2000). Creating a vaccine against anthrax. Nature Journal, 10, 4-12.

3. Sedinkin, V. V., Vishnevs'kij, O. G. (2009). Vaccination - a reliable means of preventing anthrax. Veterinary Medicine of Ukraine, 2, 32-33.

4. Hugh-Jones, M., Blackburn, J. (2009). The ecology of Bacillus anthracis. Molecular aspects of medicine, $30,356-367$.

5. Grmilov, V. S. (2011). Kherson Zemstvo leading role in establishing the national fight against epizootics of anthrax. International scientific-practical conference "The first (international) Yastrebovski reading", Kyiv, 66-70(in Ukraine).

6. Zavirjuha, G. A., Vasil'eva, T. B., Pan'ko, M. M. (2008). Comparative evaluation of cultural-morphological properties of vaccine strains of Bac. anthracisK-79Z and Bac. Anthracis SB used for the production of live vaccines against anthrax spore animals biofactoryof Ukraine. Veterinary Biotechnology: Bulletin, 12, 63-67.

7. Anthrax spore vaccine (live) for veterinary USE. 01/2008:0441. (2011). European pharmacopoeia 7.0,2,847.

8. Terrestrial Manual (2012). International standards for vaccine banks OIE. Anthrax.http:/ / www.oie.int / fileadmin/Home/eng/Health_standards/tahm/1.01.10_VACCINE_BANKS.pdf

9. Manual of Diagnostic Tests and Vaccines for Terrestrial Animals. (2015). Quality control of vaccines. OIE Terrestrial manual. http:/ / www.oie.int/fileadmin

10. Ruden', V. V., Moskv'jak, G. V., Banchuk, M. V. (2011). Legislative and regulatory adjustment process of organizing and conducting vaccination of the population in Ukraine.Kyiv, 105 (in Ukraine).

11. Levy, H.,Weiss, S., Altboum, Z., Schlomovitz, J. (2012). Differential Contribution of Bacillus anthracis toxins to pathogen city in two animal models.Infection immunity, 80(8), 2623-2631.

12. Woods, C. W., Ospanov, K., Myrzabekov, A. (2004). Risk factors for human anthrax among contacts of antrax-infected livestock in Kazakhstan. Journal The American society of tropical medicine and hygiene, 71(1), 48-52.

13. Rublenko, I. O., Skripnik, V. G. (2015). Dynamics of protysybirkovyh antibodies in the serum of sheep immunized animals against anthrax vaccine strain of Bacillus anthracis UA-07 "Antravak." Scientific Journal of Veterinary Medicine.Bila Cerkva, 54-58 (in Ukraine).

14. Skrypnyk, V., Golovko, A., Skrypnyk, A., Rublenko I. (2014). Dynamics of anthrax cases in Ukraine during 1970-2013 years. International journal of infectious diseases, 21,181. DOI: http://dx.doi. org/10.1016/j.ijid.2014.03.798

15. Sjurin, V. N., Belousova, R. V., Fomina, N. V. (1984). Veterinary virology. Moscow: Kolos, 359-361 (in Russia).

\section{АНОТАЦІЯ}

I. О. Рубленко, В. Г. Скрипник. Особливості формування спеиифічного імунітету у великої рогатої худоби після вакцинаиї вакииною проти сибірки тварин із итаму UA-07 «Антравак» // Біресурси і природокористування. - 2016. - 8, №5-6. - C.67-71.

Наведено результати порівняння показників титрів протисибіркових антитіл у сироватиі крові великої рогатої худоби, вакиинованої вакииною проти сибірки тварин із штаму Bacillus anthracis UA-07 «Антравак». Показано, що вакиина викликає стимулювальну дію в тварин усіх дослідних груп, шо виявляється у підвищенні титрів проти сибіркових антитіл. Отримані результати свідчать про домільність застосування вакиини проти сибірки тварин із итаму Bacillus anthracis UA-07 «Антравак» для вакиинаиї великої рогатої худоби.

\section{АННОТАЦИЯ}

И. А. Рубленко, В. Г. Скрипник . Особенности формирования спечифического иммунитета у крупного рогатого скота после вакиинаиии вакииной против сибирской язвы животных из штамла UА-07 «Антравак» //Биоресурсы и природопользование. - 2016. - 8, №5-6. - С.67-71.

Показаны результаты сравнения показателей титров противосибиреязвенных антител в сыворотке крови крупного рогатого скота вакиинированного вакциной против сибирской язвы животных из итамма Bacillus anthracis UA-07 «Антравак». Установлено, ито вакиина вызывает стимулируюшее действие у животных всех исследовательских групп, особенно в третьей, что пролвлялось повышением титров противосибиреязвенных антител. 